\title{
The effect of e-cigarette and a conventional cigarette to the alveolus on Wistar male rats
}

\author{
Budian Nurpangestu' ${ }^{1}$, Yusrotun Kharimah ${ }^{2}$, Fita Linggasati ${ }^{3}$, Mochamad Bahrudin ${ }^{4}$ \\ 1,2,3 Faculty of Medicine, University of Muhammadiyah Malang, Indonesia \\ ${ }^{4}$ Neurology Division, University of Muhammadiyah Malang, Indonesia
}

\section{Article Info}

Article history:

Received Jul 8, 2019

Revised Sep 7, 2019

Accepted Oct 6, 2019

\section{Keywords:}

Alveolus

Conventional cigarette

E-cigarette

\begin{abstract}
Smoking can cause a variety of diseases one of them on pulmonary organs, e-cigarettes are also considered to be safer than conventional cigarettes and the number of smokers in Indonesia is increasing every year. The purpose of this study to determine differences in pulmonary alveolar damage in male rats (Rattus norvegicus Wistar strain) on electric cigarette smoke exposure and conventional cigarettes. This research is true experimental with post-test only control group design. Male rats were used as many as 25 rats were divided into 5 groups, namely the group $\mathrm{P} 0$ as a negative control group; P1 group was exposed to clove cigarettes; $\mathrm{P} 2$ group is exposed to a filter cigarette; P3 group was exposed to e-cigarette $0 \mathrm{mg}$; P4 group exposed the ecigarette $3 \mathrm{mg}$. Samples were treated for 30 days. Data were analyzed using Kruskal Wallis with $p<0.05$. The results showed that there were significant differences in alveolar damage in the fifth group $(p=0.003)$. With Mann Whitney shows that groups P1, P2, P3, and P4 there are no significant differences. The conclusion of this study is there is no difference in alveolar damage on Wistar male rats by e-cigarettes and conventional cigarettes exposure.
\end{abstract}

Copyright (C) 2019 Institute of Advanced Engineering and Science. All rights reserved.

\section{Corresponding Author:}

Budian Nurpangestu, Faculty of Medicine, University of Muhammadiyah Malang, Malang 65145, Indonesia.

Email: budian_np@yahoo.com

\section{INTRODUCTION}

Smoking can cause a variety of health problems both on active or passive smokers. 5 According to the WHO cause of death in the world with one of the risk factors of smoking. According to the 3rd edition of The Tobacco, Atlas ASEAN is a region with $10 \%$ of the world's smokers and $20 \%$ of the causes of global mortality due to tobacco and Indonesia percentage of the population who smoke amounted to $46.16 \%$ [1]. The mean population is aged $\geq 10$ years of smoking Indonesia 12.3 stems per day (the equivalent of one pack) with the most age distribution of active daily smokers at age 30-34 years at $33.4 \%$ with the percentage of men more compared female smokers $(62.9 \%$ versus $4.8 \%)$ [2].

Cigarettes produced more than 4000 materials from burning and hundreds of them are addictive. In any suction of smoke, there are 1014 free radicals and can be maintained in a relatively long time $>10$ minutes [3]. In addition to nicotine in cigarettes are also found tar compounds, gases CO (carbon monoxide), BAP (benzopyrene), TSNA (tobacco-specific nitrosamines), pesticide residues, and other substances that are not less harmful when compared with nicotine [4]. Currently circulating e-cigarette that was first introduced in 2003 [5]. The main content of the e-cigarette glycerin, propylene glycol, water and nicotine, some other constituents of carbon monoxide (CO), carbonyls, phenolics, volatile organic compounds (volatiles), metals, tobacco-specific nitrosamines (TSNAs), polyaromatic amines (PaaS), and polyaromatic hydrocarbons (PAHs) [6]. E-cigarette users in Indonesia in 2011 reached $0.3 \%$ and in 2015 reached $2.5 \%$ of the total 
population [7] with a spread of ages $12-24$ years at $14.4 \%$ and at the age of $25-4412.4 \%$ and the number of users in the college of $29.4 \%$ [8]. At the initial appearance of e-cigarette is claimed to be safe for health because nicotine and toxic substances in an e-cigarette are lower than conventional cigarettes [9].

Seeing the problems that exist today based on data Riskesdas 2018, increasing the number of smokers in Indonesia every year and certainly will be in line with the increase in passive smokers in Indonesia, according to Department of Health \& Human Services, State Government of Victoria in 2018 states that Smoke from secondhand smoke contains carbon monoxide three times as many, 10 to 30 times more nitrosamines, and 15 to 300 times as much ammonia. Passive smokers have a risk five times more susceptible to the disease affected by active smokers, more than 40.3 million children in Indonesia live with smokers that are exposed to the smoke. They are at risk for bronchitis, pneumonia, asthma, etc. Passive smokers also cause a decrease in the level of health in adulthood. Active and passive smokers at risk for lung cancer and other cancers [10]. Electronic Cigarette Association (ECA) had not involved returning the electronic cigarette to quit smoking program because it turns out there are harmful substances in it the same as conventional. Based on a study of toxic substances such as arsenic, cadmium, tobacco-specific nitrosamines (TSNA), ammonia, carbon monoxide, aromatic amines, volatile organic compounds (VOC), nicotine, and polyaromatic hydrocarbons where all the material is not good for health [11].

In previous similar studies have been conducted observations about the lung damage that affect by e-cigarette exposure and as a result there is a histology lung damage, but these studies need to be developed because the research only 2 weeks, so the results less than the maximum and cigarette use were less variable [12] and based on other studies of pulmonology faculty of medicine university of Indonesia regarding the effects of electronic cigarette turns the electronic cigarette has harmful effects on the lungs just like a conventional cigarette. However, further research is still needed on the difference between conventional cigarettes and electronic cigarettes in long-term use. Because there are a lot of clinical data showing the effect of the use of electronic cigarettes in the long term [13], Seeing mash a little research on conventional cigarette comparison with the e-cigarette therefore in this study compared to the level of damage to cells in the alveoli of exposure conventional cigarettes and e-cigarette so hopefully with this study can add to the study of research and to develop knowledge in the medicine and science, in addition to the existence of this research could change society's view of the electric cigarette is still considered safe and become a lifestyle, especially among teenagers.

The purpose of this study was to prove the existence of differences in the level of damage to cells in the alveolar white male rats (Rattus norvegicus Wistar strain) by exposure to e-cigarettes and conventional cigarettes. Benefits expected of the program is to give knowledge to the community and medical personnel on the health effects caused by exposure to e-cigarettes and conventional cigarettes smokes, especially in the lungs, the community hopes to understand the dangers of e-cigarettes and conventional cigarettes to stop smoking.

\section{RESEARCH METHOD}

\subsection{Research design}

This type of research is experimental research (True Experiment Research) by the method of the Post Test Only Control Group Design is to do the scoring on the level of alveolar cell damage after being treated.

\subsection{Research samples}

The population and sample of this research are white male rats (Rattus norvegicus Wistar strain). The determination of the samples makes use of the formula Arifin WN \& Zahiruddin WM (2017) with a sampling technique using simple random sampling, which found the total sample of 25 male rats (Rattus norvegicus Wistar strain).

\subsection{Research group}

This study usesh the white rat as many as 25 rats were divided into five treatment groups. The first group ( $\mathrm{P} 0$ ) is the negative control group (without exposure to e-cigarette and conventional cigarette smoke), the second group (P1) was given clover cigarettes smoke, the second (P2) was given filter cigarettes smoke, the third group (P3) was given e-cigarette smoke with nicotine omg, the fourth group (P4) was given ecigarette with $3 \mathrm{mg}$ nicotine levels. Clove and filter cigarettes in 5 cigarettes in exposure 2 times per day in a period of 30 days, while e-cigarettes smoke in $3 \mathrm{~mL}$ liquid in exposure 2 times per day in a period of 30 days.

Int. J. of Adv. in Appl. Sci. Vol. 8, No. 4, December 2019: 251 - 256 


\subsection{Research procedure}

Stages smoke exposure carried out by first preparing a smoke exposure equipment. Smoking box (size 40x40x20 $\mathrm{cm}^{3}$ ) with 3 pumps, the first pump for clove and filter, a second pump for the e-cigarette and the third for free air pump where they all pump is set by Arduino. The pump will be piped to a conventional cigarette box smoking (clove and filters) and e-cigarette by using a hose. At the time of exposure to smoke, the smoking box is sealed with the supplied ventilation. Fifth mice simultaneously incorporated into the smoking box, then the box is closed again further conventional cigarettes and e-cigarette installed and the pump is turned so that the cigarette smoke into the box.

After 30 days the rats will be anesthetized prior to surgery with chloroform $0,67 \mathrm{ml}$. Lungs removed and cleaned of blood is then performed using $10 \%$ formalin fixation. After it was confirmed dead rats will be collected into one and buried. Lung organ that has been fixed histological preparations will be made by the method of paraffin and HE staining. Observations preparation using a microscope with 400x magnification and visual field observed at 5 . The microanatomy structure of the lungs was analyzed by a score of the level of damage as listed in Table 1 and Table 2 [14].

Table 1. Score level alveolar cell damage

\begin{tabular}{|c|c|c|c|c|}
\hline \multirow{2}{*}{ Histological } & \multicolumn{4}{|c|}{ Scoring } \\
\hline & 0 & 1 & 2 & 3 \\
\hline Pulmonary edema & $\begin{array}{l}\text { no changes in } \\
\text { histological structure }\end{array}$ & $\begin{array}{l}\text { pulmonary edema at } \\
\text { less than a third of the } \\
\text { field of vision }\end{array}$ & $\begin{array}{l}\text { pulmonary edema at one- } \\
\text { third to two-thirds of the } \\
\text { field of vision }\end{array}$ & $\begin{array}{l}\text { pulmonary edema in } \\
\text { more than two-thirds of } \\
\text { the field of vision }\end{array}$ \\
\hline $\begin{array}{l}\text { Destruction of the } \\
\text { alveolar septum }\end{array}$ & $\begin{array}{l}\text { no changes in } \\
\text { histological structure }\end{array}$ & $\begin{array}{l}\text { Destruction of the } \\
\text { alveolar septum at less } \\
\text { than a third of the field } \\
\text { of vision }\end{array}$ & $\begin{array}{l}\text { Destruction of the } \\
\text { alveolar septum at one- } \\
\text { third to two-thirds of the } \\
\text { field of vision }\end{array}$ & $\begin{array}{l}\text { Destruction of the } \\
\text { alveolar septum more } \\
\text { than two-thirds of the } \\
\text { field of vision }\end{array}$ \\
\hline Inflammatory Cells & histological structure & $\begin{array}{l}\text { Inflammatory Cells at } \\
\text { less than a third of the } \\
\text { field of vision }\end{array}$ & $\begin{array}{l}\text { Inflammatory Cells at } \\
\text { one-third to two-thirds of } \\
\text { the field of vision }\end{array}$ & $\begin{array}{l}\text { Inflammatory Cells } \\
\text { more than two-thirds of } \\
\text { the field of vision }\end{array}$ \\
\hline
\end{tabular}

A score of three parameters in each field of view will be averaged, the average yield to determine the extent of the damage. Then the rate of lung damage that has been obtained is classified based on the assessment criteria alveolar cell damage level consisting of:

Table 2. Criteria for evaluation of alveolar damage

\begin{tabular}{ccc}
\hline Criteria & Information & value Variation \\
\hline Normal & There are no histological changes & 0 \\
Minor damage & Pulmonary alveolar damage $>0 \%-<30 \%$ of the maximum damage & 1 \\
Moderate damage & Pulmonary alveolar damage $>30 \%-<60 \%$ of the maximum damage & 2 \\
Severe damage & Pulmonary alveolar damage $>60 \%$ of maximal damage & 3 \\
\hline
\end{tabular}

\subsection{Data analysis research}

In this study, the data obtained from A score of three parameters in each field of view will be averaged, the average yield to determine the extent of the damage. Then the rate of lung damage that has been obtained is classified based on the assessment criteria alveolar cell damage level. Data will be processed using SPSS 24 and tested by Kruskal Wallis test and Mann-Whitney post hoc.

\section{RESULTS AND DISCUSSIONS}

Results of research on the differences in exposure to e-cigarette and ordinary cigarette against damage of the lung alveoli white male rats Rattus norvegicus obtained data on individual research groups in Table 3. In this study the state of the whole rat alive and there are no exclusion criteria so that all the samples are met, namely amounting to 25 animals. Data obtained in the form ordinal data that are divided into four categories ie normal alveolar damage, minor damage, moderate damage and severe damage where the data is obtained from the average of the value of the parameter scoring damage in the form of pulmonary edema, alveolar septal destruction, and inflammatory cell infiltration. 
Table 3. Alveolar damage observed data of each group

\begin{tabular}{cccccc}
\hline Group & Normal & Minor damage & Moderate damage & Severe damage & Mean \\
\hline K & 1 & 4 & - & - & 3.40 \\
P1 & 0 & 0 & 4 & 1 & 15.90 \\
P2 & 0 & 0 & 3 & 2 & 17.80 \\
P3 & - & 1 & 4 & - & 12.00 \\
P4 & - & - & 4 & 1 & 15.90 \\
\hline
\end{tabular}

Information:

P0: Negative control group, only given food and drink standards for 30 days,

P1: Rats were given food and drink standards and being exposed to clove cigarette smoke with 5 clove cigarettes in exposure 2 times a day for 30 days.

P2: Rats were given food and drink standards and are exposed to filter cigarette smoke with 5 filter cigarettes in exposure 2 times a day for 30 days.

P3: Rats were given food and drink standards and being exposed to $\neg$ e-cigarette smoke with $0 \mathrm{mg}$ nicotine in $3 \mathrm{~mL}$ liquid in exposure 2 times a day for 30 days.

P4: Rats were given food and drink standards and being exposed to $\neg$ e-cigarette smoke with $3 \mathrm{mg}$ nicotine in $3 \mathrm{~mL}$ liquid in exposure 2 times a day for 30 days.

Data from Table 3 is known that the average value of the group P0 alveolar damage (3.40) showed minor damage. The average value of alveolar damage at the P1 group (15.90) showed moderate damage, the average value of alveolar damage in group P2 (17.80) showed moderate damage, the average value of alveolar damage at $\mathrm{P} 3$ group $(12,00)$ showed moderate damage. While the average value of alveolar damage in group P4 (15.90) showed moderate damage. In the calculation using the Kruskal Wallis p-value $=0.003$ it showed $\mathrm{p}<0.005$, it was concluded there is a significant difference in all groups.

Statistical calculations of the Mann Whitney test were conducted to determine major differences between the treatment groups by looking at the larger value of each group. The results of the Mann Whitney test in Table 4 indicates a significant difference from P0-P1, P0-P2, P0-P3, P0-P4. While the results of the comparison between the treatment groups P1, P2, P3, P4 showed no significant difference. Histology and overview picture of alveolus lung damage criteria with 400x magnification shown in Figure 1 and Figure 2.

Table 4. Statistical analysis comparing alveolar damage in each group (Post Hoc Mann Whitney test)

\begin{tabular}{cccccc}
\hline Treatment group & P0 & P1 & P2 & P3 & P4 \\
\hline P0 & - & 0,005 & 0.006 & 0.015 & 0.005 \\
P1 & 0.005 & - & 0.513 & 0.180 & 1.000 \\
P2 & 0.006 & 0.513 & - & 0.093 & 0.513 \\
P3 & 0.015 & 0.180 & 0.093 & - & 0.180 \\
P4 & 0.005 & 1.000 & 0.513 & 0.180 & - \\
\hline
\end{tabular}

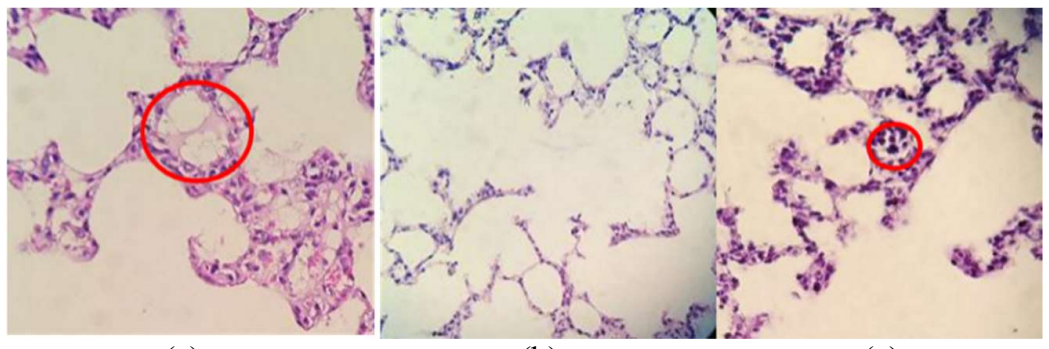

(a)

(b)

(c)

Figure 1. Histology picture alveolus lung damage criteria with 400x magnification (a) Pulmonary edema, (b) Destruction of the alveolar septum, (c) Inflammatory cell infiltration 


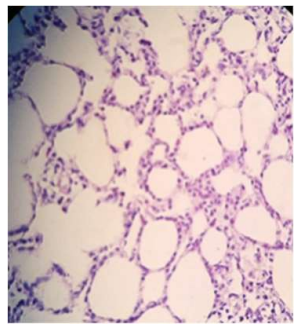

(a)

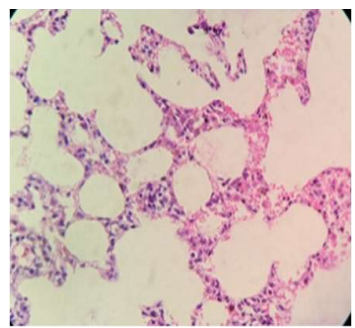

(b)

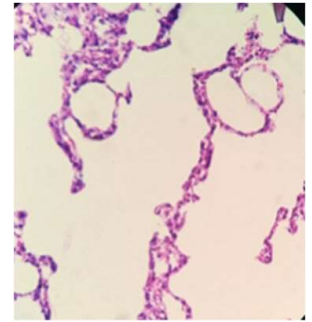

(c)

Figure 2. Overview histology lung damage alveolus with 400x magnification (a) Minor damage, (b) Moderate damage, (c) Severe damage

A significant difference between the control group and the treatment group because of the treatment groups give a conventional cigarette smoke exposure and the e-cigarettes smoke. The smoke from a cigarette can make the cilia paralyzed in a few hours, with repeated exposure eventually cause damage to the cilia. The inability of the cilia in sweeping out mucus containing foreign particles that constantly comes causing carcinogens inhaled to remain in the respiratory tract for a long time. In addition, cigarette smoke paralyzes the alveolar macrophages. Particles in cigarette smoke not only cripple the macrophages but also certain substances from tobacco smoke have a toxic effect directly on macrophages, which reduces the ability of macrophages to engulf foreign bodies. In addition, the toxic substances in tobacco smoke also cause irritation of the mucosal lining of the airways, causing excessive mucus production, and will indirectly partially clog the airways [15]. Smoking is one of the pollutants in the form of a gas containing a variety of chemicals including nicotine, carbon monoxide, tar and eugenol (clove cigarettes). Cigarette smoke is a source of free radicals can affect the metabolism of macrophages [16].

Alveolar macrophages stimulated by exposure to cigarette smoke will occur inactivation of $\alpha 1-\mathrm{AT}$ as proteinase inhibitor and secrete proinflammatory cytokines (TNF- $\alpha$, IL-1, IL-2, IL-8, LTB4) in the lungs via two pathways, namely by way of metalloenzyme elastase production as having a role in $\alpha 1$-AT hydrolyze and produce reactive oxygen species (ROS) that will inhibit $\alpha 1-\mathrm{AT}$. Elastase can damage lung structures of proteins, one of which is the destruction of the alveolar septum [17].

A significant difference between the treatment groups P1, P2, P3, P4 due to exposure to smoke conventional cigarettes and e-cigarette. In the treatment group, conventional cigarettes are nicotine, carbon monoxide causes barriers proliferation of fibroblasts and elastin tissue damage that causes dilation of the alveoli, whereas tar substances can cause lung damage and are carcinogenic substances. The content of the ecigarette smoke other than nicotine, carbon monoxide contained propylene glycol compound where after heated to produce formaldehyde which is a carcinogenic substance that is found also in conventional cigarettes. The content of the smoke conventional cigarettes and e-cigarettes cause lung histology damage [18]. Pulmonary edema may occur due to increased airway resistance due to exposure to foreign particles in cigarette smoke that occurs continuously or intravascular pressure high due to increased permeability of capillary endothelium resulting in extravasation of fluid in tissue interstitial quickly, therefore, occur obstacle air exchange in the alveoli are progressive, Increased capillary permeability will cause the activation of neutrophils and occurs aggregation of neutrophils, causing neutrophils inherent in endothelial cells and the release of free radicals, toxins and inflammatory mediators that cause alveoli filled by exudates rich in protein and contains many inflammatory cells including neutrophils, the primary source of protease cell are neutrophils, PMN cells, pulmonary alveolar macrophages (PAM), $\alpha 1$-AT that can occur destruction of elastic tissue becomes uncontrollable [19]. The imbalance of protease cell and elastase release by the working mechanism of inactivation leukoprotease inhibitor in particular the degradation of cells and the extracellular matrix will result in the integrity of elastic fibers and collagen is reduced so that the connective tissue is destroyed and the destruction of the septum alveolar, an increase in inflammatory cells such as neutrophils and macrophages because these pollutants from cigarette smoke cause proteolysis [20,21].

\section{CONCLUSION}

Based on the research showed there were no differences in lung alveolar damage in rats both exposed to e-cigarette and conventional cigarettes. 


\section{ACKNOWLEDGEMENTS}

The author's wishes thank almighty God and the ministry of research, technology and higher education Indonesia who fund and support this research. Thank all the lecture in the University of Muhammadiyah Malang, all the laboratory staff in campus and hospital in the University of Muhammadiyah Malang, my parent, my family and all of my friends who participated in this research.

\section{REFERENCES}

[1] Infodatin, The Indonesian Society Smoking Behavior, Data and Information Center for the Ministry of Health of the Republic of Indonesia, Jakarta, pp. 12-15, 2015.

[2] Riskesdas, Problems Smoking in Indonesia, Agency for Health Research and Development of the Republic of Indonesia, Jakarta, pp. 5-6, 2018.

[3] Mudjiwijono HE, Nunuk SM, SN Beautiful, "Tomatoes Juice bronchus Ephitelial Reduce Cell in Rat with Chronic Sub Exposed to Cigarette Smoke," Brawijaya Medical Journal, vol. 26(1), pp.1-3, 2010.

[4] Tirtosastro S, Murdiyati A, The Chemical Ingredients of Tobacco and Cigarettes, Research and Development Ministry of Agriculture, Malang, pp. 33-43, 2010.

[5] US Department of health and human services, How Tobacco Smoke Causes, MD: Public health services, Rockville, pp. 8-12, 2016.

[6] FDA, Reporting Harmful and Potentially Harmful Constituents in Tobacco Products and Tobacco Smoke Under Section 904 (a) (3) of the Federal Food, Drug, and Cosmetic Act, the US Department of Health and Human Services Food and Drug Administration's Center for Tobacco products (CTP), USA, p. 4, 2012.

[7] K. Palipudi, J. Mbulo, J. Morton, et al., "Awareness and current use of electronic cigarettes in Indonesia, Malaysia, Qatar, and Greece: Findings from the 2011-2013 Global Adult Tobacco Surveys," Nicotine and Tobacco Research, vol. 3(2), pp. 1-7, 2015.

[8] T. Bam, W. Bollow, I. Berezhnova, M. Jackson, A. Jones, and E. Latif, "Position Statement on the electronic cigarette or electronic nicotine delivery systems," Int. J. Tuberc. Lung Dis., vol. 18(1), pp. 5-7, 2014.

[9] M. William, A. Trtchounian, and P. Talbot, "Conventional and electronic cigarette (e-cigarette) smoking have different characteristics,” Nicotine Tobacco Res., vol. 12, pp. 905-912, 2010.

[10] Department of Health, State Government of Indonesia, Indonesia Health Profile 2016, Jakarta: Ministry of Health RI, 2017.

[11] J. Flora, N. Meruva, C. Huang, C. Walkinson, et al., "Characterization of potential impurities and degradation products in electronic cigarette formulations and aerosols," Regulatory Toxicology and Pharmacology, vol. 74, p. 4, 2016.

[12] N. Triana, S. Ilyas, and S. Hutahaean, "Histological Overview of Pulmo Male Mice (Mus musculus L.) After being exposed Smoke Electric (in Bahasa), Saintia Biology, vol. 1(2), pp. 1-7, 2013.

[13] R. Tanuwihardja and A. Susanto, "Electronic cigarettes (electronic cigarettes)," Indonesia Respiratory Journal, vol. 32(1), pp. 53-61, 2012.

[14] T. Hansel and P. Barnes, An Atlas of Chronic Obstructive Pulmonary Disease. Parthenon Publishing Group, London, pp. 22-36, 2004.

[15] Sherwood L., Fisiologi Manusia dari Sel ke Sistem, Ed. 8. EGC, Jakarta, pp. 483-488, 2013.

[16] M. Dietrich, B. Gladys, P. Edward, H. Mark, G. March, E. Carroll, and P. Lester, "Smoking and exposure to environmental tobacco smoke decrease some plasma antioxidants and increase of tocopherol in vivo after adjustment for dietary Antioxidants intakes," Am. J. Clin. Nutr., vol. 77(1), p. 3, 2009.

[17] V. Kumar, A. Abbas, and J. Aster, Robbins Basic Pathology, Ed. 9. Elsevier, Canada, pp. 465-481, 2013.

[18] C. Varvadas, N. Anagnostopoulos, M. Kouglas, V. Evangelopoulou, G. Connolly, and P. Behrakis, "Short-term pulmonary effects of using an electronic cigarette: impacton respiratory flow resistance, impedance, and exhaled nitric oxide," Chest, vol. 141(6), pp. 1400-1406, 2012.

[19] D. Sargowo, D. Adiputro, M. Widodo, and R. Romdoni, "Extract of mangoosteen increases high-density lipoprotein levels in rats fed a high lipid," Universa Medicina Journal, vol. 32(1), pp. 37-43, 2013.

[20] M. Mohan, T. Dutt, and R. Ranganath, "Tobbaco smoking related interstitial lung diseases," The Indian Journal of Chest Diseases and Allied Sciences, vol. 54(1), pp. 243-9, 2012.

[21] A. Petta, "Histopathological characteristics of pulmonary emphysema in experimental models," Einstein, vol. 12(3), pp. 382-383, 2014. 